\title{
The Perception of Social Safety in a Green Environment: A preliminary study at the Kepong Metropolitan Park
}

\author{
Srectheran Maruthaveeran \\ Forest Research Institute Malaysia (FRIM). \\ 52109. Kepong, Selangor Darul Ehsan, Malaysia \\ srertherantsifrim.govrnv
}

\begin{abstract}
Although there are many positive benefits gained from green areas, it is possible that people also have a negative perception towards such areas. Previous studies have shown that natural areas are sometimes perceived as scary, disgusting and uncomfortable when the sites are more densely vegetated, particularly when the vegetation is not apparently maintained and crime is often cited as a reason to avoid densely wooded areas. Based on this notion. a preliminary survey was conducted at Kepong Metropolitan Park. A total 0/69 park users were interviewed. A questionnaire was designed to provide information on the users' perception $0 /$ personal safety based on vegetation composition in urban parks. The perception of personal safety was based on photos taken before the survey. These photographs were taken at several urban parks in Kuala Lumpur. Out of 66 photographs taken. only 24 photographs were chosen for this study. The selection of the photographs was based on the type of vegetation such as topiary, young trees, matured trees. open space. hedges, shrub. water plant, bamboo, non-woody plants, and palms. Each of these photographs was identified with a numbered label. The respondents were requested to assess the type of surrounding vegetation they regarded as providing the safest environment. This study indicated that a photograph representing topiary plants was chosen by most park users as providing the safest park environment. On the other hand, a photograph depicting a pool with tall water grasses was considered as providing the least secure environment. This preliminary study revealed that people preferred parks which are more organized, maintained and well managed with a 'more formal' landscape setting. This study only presents preliminary evidence for the idea that a green environment can contribute towards fear and the feeling of being unsafe.
\end{abstract}

Keywords: Garden Nation, environmental design, public space, safe city, fear

eISSN 2514-751X @ 2016 The Authors. Published for AMER ABRA by e-International Publishing House, Ltd., UK.. This is an open access article under the CC BY-NC-ND license (http://creativecommons.org/licenses/by-nc-nd/4.0/). Peer-review under responsibility of AMER (Association of Malaysian Environment-Behaviour Researchers), ABRA (Association of Behavioural Researchers on Asians) and cE-Bs (Centre for Environment-Behaviour Studies), Faculty of Architecture, Planning \& Surveying, UniversitiTeknologi MARA, Malaysia.

https://doi.org/10.21834/aje-bs.v1i1.171 


\subsection{Introduction}

The majority of research on urban parks in Malaysia focuses on the usage and recreational needs of the user. However, few studies link vegetation to fear and crime in urban parks. In the excitement of transforming Malaysia into a Garden Nation through planting trees and establishing public parks around the Federal Territory of Kuala Lumpur, special attention should also be given to the type of vegetation in our urban parks in order to provide a safer environment.

Apart from the many positive benefits and meanings gained from green areas, people might also have negative perceptions on parks. Many people fear natural areas for safety reasons. Green spaces or urban parks are not liked by everyone all the time. There are existing sites which are underused, in part because they are often seen as threatening places where crime could frequently occur. Studies have shown that natural areas are sometimes perceived as being scary, disgusting and uncomfortable. Parks are also perceived as risky when the sites are more densely vegetated, particularly when the vegetation is not apparently maintained and crime is often cited as a reason to avoid densely wooded areas. People prefer parks which are more organized, maintained and managed or having a 'more formal' landscape setting. However, this does not mean parks always invite crime. The implementation of the National Urbanisation Policy and the Kuala Lumpur Structure Plan 2020 for creating a safer urban environment, has stirred the researcher's interest to conduct a preliminary study to assess the perception of personal safety based on vegetation composition in urban parks by using photographic images.

\subsection{Literature Review}

Although there are many positive benefits and meanings gained from green areas, people may also have negative perceptions about such areas. Many people fear natural areas for safety reasons. Social safety refers to safety resulting from human behaviour and interactions between people in public space (Van Winsum-Westra and De Boer, 2(04). Safety can be judged both objectively (safety measured by facts and figures) and subjectively (perceived safety experienced by the individual) (Van Winsum-Westra and De Boer, 20(4). Objective social safety may differ from subjective social safety but in terms of behavioural constraints, it is subjective safety which influences behaviour and which causes people to avoid places they associate with insecurity (Maas, J. et al., 20(8).

As early as 1285 , King Edward I attempted to reduce highway robbery by forcing property owners to dear highway edges of trees and shrubs (Pluncknett, 1960). Green spaces or urban parks are not liked by everyone all the time. Green space can be perceived as dangerous because it may facilitate crime by providing a hiding place for perpetrators of crime and may conceal criminal activity (Herzog and Flynn-Smith, 2001; Van Winsurn-Westra and De Boer, 2(04). There are existing sites which are underused, in part because they are often seen as threatening places where crime frequently occurs (Jacobs, 
1961). Previous studies have shown that natural areas are perceived as scary, disgusting and uncomfortable (Bixler and Floyd, 1997). Parks are also perceived as risky when the sites are more densely vegetated, particularly when the vegetation is not apparently maintained (Schroeder, 1989; Michael and Hull, 1994) and crime is often cited as a reason to avoid densely wooded areas (Talbot and Kaplan, 1984). People prefer more natural looking areas which are more organized, maintained and managed or have a 'more formal' landscape setting (Kaplan, 1984: Schroeder and Anderson, 1984; Burgess et al., 1988, Millward and Mostyn, 1989 and Ozguger, H. and Kendle, A.D., 2(06), a hiding place for perpetrators of crime and may conceal criminal activity (Herzog and Flynn-Smith, 2001; Van Winsurn-Westra and De Boer, 2(04). There are existing sites which are underused, in part because they are often seen as threatening places where crime frequently occurs (Jacobs, 1961). Previous studies have shown that natural areas are perceived as scary, disgusting and uncomfortable (Bixler and Floyd, 1997). Parks are also perceived as risky when the sites are more densely vegetated, particularly when the vegetation is not apparently maintained (Schroeder, 1989; Michael and Hull, 1994) and crime is often cited as a reason to avoid densely wooded areas (Talbot and Kaplan, 1984). People prefer more natural looking areas which are more organized, maintained and managed or have a 'more formal' landscape setting (Kaplan, 1984: Schroeder and Anderson, 1984; Burgess et al., 1988, Millward and Mostyn, 1989 and Ozguger, H. and Kendle, A.D., 2(06).

Parks are also less preferred when perceived to be the setting for drinking, drug use, crime, teenage hangouts, rowdy behaviour and clashes with rangers (Schroeder, 1989). This may be true because safety and security is one of the six human needs besides physiological (e.g. food and shelter), affection belonging (need to belong to a group or community), esteem (need to be accepted), selfactualization (fulfilment of potential) and cognitive-aesthetic needs (Maslow, 1954). However, this does not mean parks always invite crime. A well-maintained, grassy area certainly does not block views; widely spaced, high-canopy trees have minimal effect on visibility; and flowers and low growing shrubs seem unlikely to provide cover for criminal activities (Kuo and Sullivan, 2001). In other words, whenever vegetation blocks views, the fear of crime is higher (Fisher and Nasar, 1992; Kuo, Bacaicoa and Sullivan, 1998; Michael and Hull, 1994).

Among urbanites' range of psychological and behavioural reactions to crime are distrusting others, avoiding particular places, taking protective action, changing their daily activities and participation in collective action (Miethe, 1995). Only recently, attempts have been made to refine the study of crime ecology. This was done by examining precisely the settings in which criminal acts have occurred (e.g., Ley and Cybriwsky, 1974) and users' perception of crime risk in different settings (Nasar, 1982). However, studies on crime ecology are still limited in this region. The absence of good information and the extensive press coverage given to criminal activity occurring in public places like parks, have established possibly underserved reputation for parks as high risk crime areas. This reputation discourages many potential site visitors from using and enjoying available recreation resources (Schroeder and Anderson, 1984). In addition, the public are also afraid 
of becoming the victims ofphysical or sexual assault, robbery or bullying and intimidation from young people in the woodland (Burgess et al., 1988; McNaghten and Urry, 2000; Jorgensen et al., 20(7). Densely wooded areas have consistently been associated with fear. A study by Schroeder and Anderson (1984) showed that indi viduals felt most vulnerable in densely forested areas and safest in open, moved areas. Another study by Talbot and Kaplan (1984) indicated that heavily vegetated areas seemed dangerous. In safety ratings for 180 scenes of parking lots, the more an area is covered by vegetation, the lower the perceived security (Shaffer and Anderson, 1985). In another study examining fear of crime in a university campus, dense undergrowth that reduced views into areas where criminals might hide were associated with fear of crime (Nasar \& Fisher, 1993). Fear of crime is higher where vegetation block views (Fisher and Nasar, 1992, Kuo, Bacaicoa, and Sullivan, 1998; Michael and Null, 1994). It has been argued that formal or ornamental landscape is strongly valued by urban people who have been subjected to the neat and tidy approach of flowerbeds and mown grass in cities for sometime (Kendle and Forbes, 1997).

The abovementioned studies show that dense vegetation provides potential cover for criminal activities, possibly increasing the likelihood of crime and certainly increasing the fear of crime. Large shrubs, underbrush and dense woods all substantially diminish visibility and therefore are capable of supporting criminal activity (Kuo and Sullivan, 2(01). It shows that not all type of vegetation blocks view. A well maintained grassy area certainly does not block views; widely spaced, high canopy trees have minimal effect on visibility and flowers and low-growing shrubs seems unlikely to provide cover for criminal activity (Kuo and Sullivan, 20(1). However there are also studies that show that vegetation deters crime. For example Nasar (1982), found that higher levels of vegetation were associated with less fear of crime. Another study that used drawings of residences found that properties appeared safer when trees and shrubs were included than when they were not (Brower, Dockett and Taylor, 1983). These contrasting findings have prompted the present study to assess the perception of personal safety based on vegetation composition in urban parks.

\subsection{Methodology}

\subsection{Data collection}

A survey was conducted in June 2007 at the Kepong Metropolitan Park. A total of 69 park users were interviewed. The survey method, based on a detailed questionnaire, was designed to interview users within the park. The selection of respondents was through random sampling. Interviewers approached each potential participant and introduced themselves by reciting or reading the following statement.

"Hello, I'm (your name) from the Forest Research Institute Malaysia (FRIM) and we are conducting a study to assess the perception of personal safety based on vegetation composition in urban parks by using a photographic method." 
The questionnaire was designed to reveal the perception of personal safety based on vegetation composition in urban parks. The perception of personal safety was based on photos taken before the survey. These photographs were taken in several urban parks in Kuala Lumpur. Out of the 66 photographs taken, only 24 photographs were chosen for this study. This was based on the type of vegetation such as topiary, young trees, matured trees, open space, hedges, shrub, water plant, bamboo, non-woody plants, and palms. The selected photos were developed into 2" 0 3" prints and pasted into a clear file for easy handling. Each of these photographs was identified with a number. Visitors were then asked to rate the 24 photos by using a 5-point numerical rating scale ( $\mid==$ very unsafe, $2==$ unsafe, $3==$ moderately safe, $4==$ safe and $5==$ very safe). This was followed by two questions on which photograph best describe the scenes with the highest and lowest security. The visitors were also asked reasons for choosing the photographs. The interviewer concluded by requesting additional descriptive information (e.g., education background) from the participants.

\subsection{Data analysis}

Questionnaire data were entered and analysed using SPSS statistical software. Descriptive analysis provided means, standard deviations and frequencies to describe the sample and variables of interest. A Reliability Test was carried out using Cronbach alpha. The choice of Cronbach is a better estimate of internal consistency of measures than other techniques (Corina, 1993).

\subsection{Results and Discussions}

\section{Socio-Demographic Profile of the Respondents}

Male respondents formed the majority (55.1\%) of the study sample and over half $(50.7 \%)$ of the total respondents were aged between 21-30 years old. The majority of the respondents were degree holders (34.8\%). Most of the respondents were government servants who earned an average monthly income between RM 100 I-RM 3000. A more detailed description is given in Table I.

\section{Rating for Perceived Personal Safety on Vegetation Composition}

A reliability test was carried out using the calculation of Cronbachs alpha coefficient for the set of 24 photographs on the perceived personal safety based on vegetation composition in urban parks. The Cronbach's alpa coefficient was 0.866 , which was found to be relatively high. This value is above the cut-off criterion of 0.7 recomm end ed by Corina (1993). The mean score for each of the photos was ca lculated and the result s are represented in Table 2. Out of 24 photographs, 19 photographs sco red a mean value of more than 3 (safe). Photo 6 (Fig. I) sco red a mean value of 4.32 and was chose $n$ as the sce ne considered safest by 
the respond en ts. Photograph no. 6 represent s a topiary plant. According to the respond ents the main reaso $\mathrm{n}$ for choosi $\mathrm{ng}$ th is photogra ph was because it was well maintained, had more space avai lable aro und the plant (thus providing a dear view), were made up of small plant s and was not bushy. It has been argued that ornamental landscape (e.g. topia ry) is strongly valued by urban people who have been subjected to the neat and tidy approach of flowerbeds and mown grass in cities for sometime (Kendle and Forbes, 1997). Photo 23 (Fig. 2) (4. 19) represent $s$ dense tree ca nopies, but these trees have high ca nopies which increases the visibi lity, and re flects spaciousness and cleanliness. Other scenes such as Photo 18 (Fig. 3) also score $d$ a rela tivel y high mean value (4.06) and they rep resent flowers and low-growing shrubs which seem unlik ely to provide an idea I place for perpetrators to hide.

$\begin{array}{ll}\begin{array}{c}\text { Table 1: Respondents's socio-demographic profile } \\ \text { Total } \\ \text { Demographic }\end{array} & \begin{array}{c}\text { (N=69) } \\ \text { Gender (\%) }\end{array} \\ \text { Male } & 55.1 \\ \text { Female } & 44.9\end{array}$

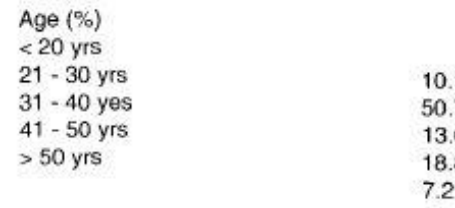

$\begin{array}{ll}\text { Education (\%) } & \\ \text { Primary School } & \\ \text { SRP/PMR } & 2.9 \\ \text { SPM } & 7.2 \\ \text { STPM } & 30.4 \\ \text { Bachelors Degree } & 8.7 \\ \text { Master Degree } & 34.8 \\ \text { No formal education } & 2.9 \\ & 13.0 \\ & \\ \text { Occupational (\%) } & \\ \text { Government Servant } & 43.5 \\ \text { Firma } & 4.3 \\ \text { Self Employment } & 8.7 \\ \text { Others } & 43.5 \\ & \\ \text { Monthly income } & \\ \text { <RM 1000 } & \\ \text { RM1001-RM3000 } & 13.0 \\ \text { RM3001-RM5000 } & 42.0 \\ \text { RM5001-RM10000 } & 1.4 \\ \text { > RM 10001 } & 7.2 \\ \text { Not earning } & 2.9 \\ & 33.3\end{array}$




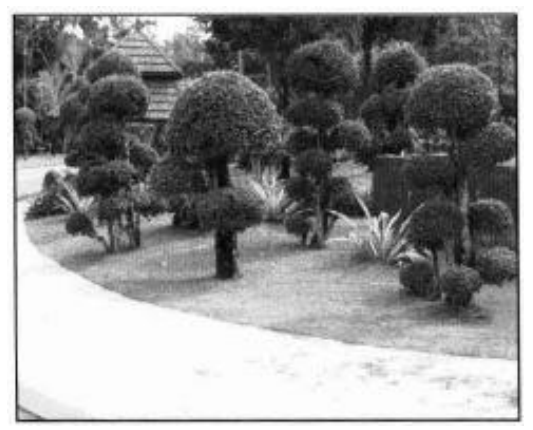

Figure 1: Photo 6 shows a topiary plant in one of the parks in Kuala Lumpur. According to the respondents the topiary plants looks well maintained, spacious between the plants, not tall and increase visibility

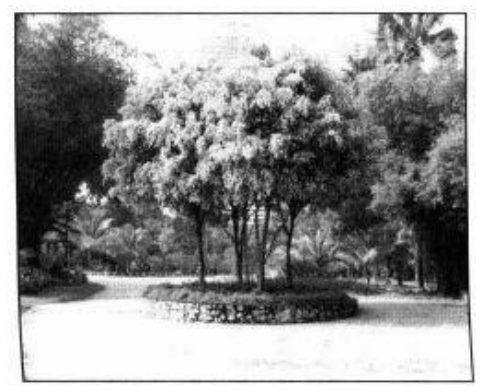

Figure 2: Photo 23 represents a dense tree canopies, but these trees have high canopies which increases the visibility, spacious and looks clean. These features make people feel safe in parks.

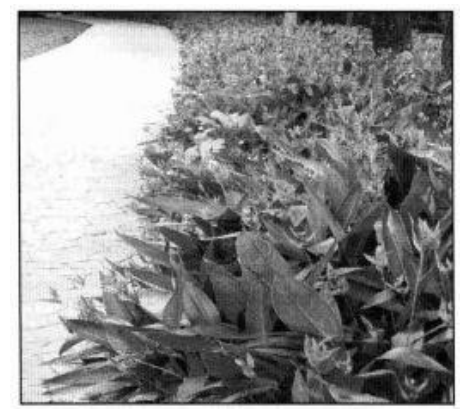

Figure 3: Photo 18 shows a row of Heliconia sp. Even tough this photo shows thick vegetation but it is well maintained and does not block views . 
Maruthaveeran, S., / Asian Journal of Environment-Behaviour Studies, ajE-Bs, 1(1), Maiden, December 2016 (p.99-111)

Table 2: Mean rating and reasons of perceived personal safety by the park visitors ( $N=69)$

\begin{tabular}{|c|c|c|c|}
\hline Photo & Mean & $\begin{array}{l}\text { Std. } \\
\text { Deviation }\end{array}$ & Reasons \\
\hline Photo 6 & 4.32 & .737 & $\begin{array}{l}\text { small size tree, no sharp objects, short trees, not } \\
\text { bushy, spacious, neat, easy to escape, well } \\
\text { maintained, bright, clear view. }\end{array}$ \\
\hline Photo 23 & 4.19 & .809 & focal point, spacious, maintained, clean. \\
\hline Photo 18 & 4.06 & .838 & short and small plants, peaceful, small flowers. \\
\hline Photo 15 & 3.97 & .804 & $\begin{array}{l}\text { near the road, attractive, comfort able, clean, } \\
\text { maintained, peaceful feeling, wide pathway. }\end{array}$ \\
\hline Photo 24 & 3.96 & .962 & open space, no obstruction. \\
\hline Photo 8 & 3.96 & 1.117 & $\begin{array}{l}\text { open space, no trees, flat ground, no obstruction, no } \\
\text { vegetation, large area, spacious, short grass, view } \\
\text { not blocked. }\end{array}$ \\
\hline Photo 3 & 3.94 & .983 & $\begin{array}{l}\text { spacious between trees, have path, flat ground, } \\
\text { bright, not many plants, open space, fenced. }\end{array}$ \\
\hline Photo 20 & 3.78 & .855 & beside building, small trees, maintained, clean. \\
\hline Photo 5 & 3.67 & .995 & Open \\
\hline Photo 2 & 3.61 & 1.018 & open, no obstacles. \\
\hline Photo 7 & 3.55 & 1.105 & - \\
\hline Photo 13 & 3.51 & 1.066 & $\begin{array}{l}\text { open space, large area, big trees, big branches, old } \\
\text { trees. }\end{array}$ \\
\hline Photo 22 & 3.48 & 1.066 & spacious, not hazard \\
\hline Photo 11 & 3.38 & .898 & - \\
\hline Photo 19 & 3.35 & .937 & tall bushes, congested. \\
\hline Photo 21 & 3.35 & .997 & clean. \\
\hline Photo 16 & 3.32 & 1.312 & no railings, unfenced. \\
\hline Photo 1 & 3.09 & .966 & open, no fence. \\
\hline Photo 14 & 3.07 & 1.102 & $\begin{array}{l}\text { many trees, lonely, unmaintained, tall, dark, not } \\
\text { clean, isolated, broken branches. }\end{array}$ \\
\hline Photo 12 & 2.97 & .822 & dead tree, sloppy, no fence. \\
\hline Photo 4 & 2.78 & .998 & $\begin{array}{l}\text { branches could fall, brittle branches, hazardous } \\
\text { trees, many trees, afraid of tree failing, branches not } \\
\text { pruned. }\end{array}$ \\
\hline Photo 10 & 2.43 & .915 & $\begin{array}{l}\text { messy, big trees, dense trees, not fenced, pathway } \\
\text { look small, , not bright, plants too close, tall and thick } \\
\text { plants. }\end{array}$ \\
\hline Photo 9 & 2.28 & .820 & $\begin{array}{l}\text { dark, hidden, bumpy surface, open drain, failing } \\
\text { branches, unmaintained, leaning trees. }\end{array}$ \\
\hline Photo 17 & 2.03 & .985 & $\begin{array}{l}\text { no hedges, no fence, muddy, children easily fall, toxic } \\
\text { material, mosquito, disease, dirty pond, no } \\
\text { systematic planting, no warning sign, swampy, } \\
\text { unmaintained. }\end{array}$ \\
\hline
\end{tabular}

Note: Rating of perceived safety: (1=very unsafe, 2 = unsafe, $3=$ safe, $4=$ very safe and 5 = extremely safe). 
On the other hand, photo 17(Fig.4)was considered the most unsafe scene. Photo 17 represents a scene of a pool with tall water grasses. However, the tall water grasses did not seem to block the view. This scene possibly makes the respondents feel unsafe because the area looked unmaintained, with long grasses (making it an easy place to hide) and the pool had murky water and therefore considered a place for mosquito breeding. Photo 9 (Fig. 5) (2.28) which consists of the heavily vegetated Acacia sp. trees was considered not maintained, dangerous, dark by the respondents. Photo 10 (Fig. 6) which also scored a lower mean value (2.43) had a row of palms with lower shrubs along a pathway. These palms were considered bushy, too dense and dark. This result agreed with other studies where dense unmaintained vegetation has been linked to a fear of crime (Shaffer and Anderson, 1985; Nasar and Fisher, 1993; Michael and Hull, 1994; Kuo, Bacaicoa \& Sulli van).

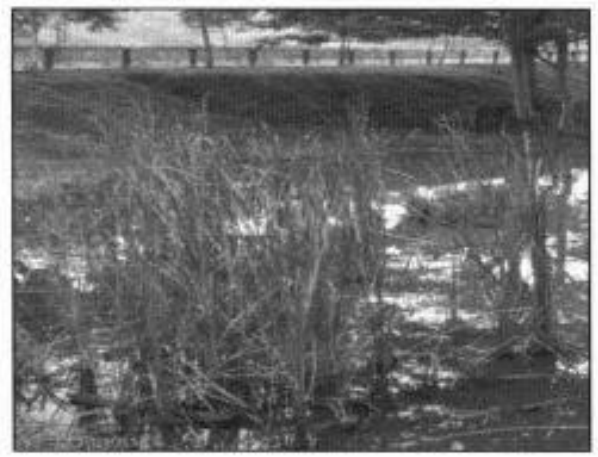

Figure 4: Photo 17 shows unmaintained vegetation , murky water and a place for mosquito breeding

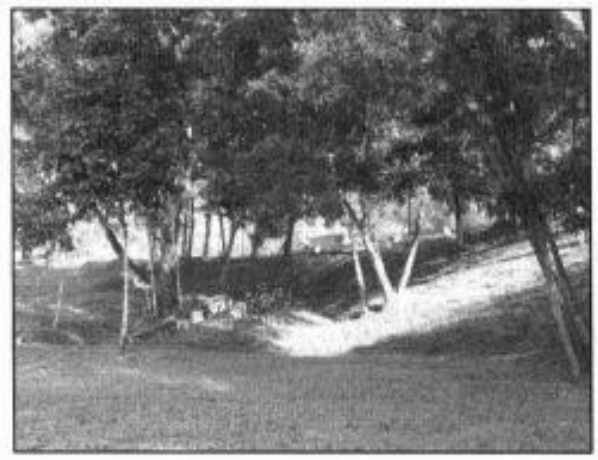

Figure 5: Dense vegetation, unmaintained and dark condition of Photo 9 creates feeling of social safety among park users

Traditionally, the belief has been that vegetation facilitates crime because it hides 
perpetrators from view. However, this study shows that the respondents felt safe in a surrounding with vegetation in a natural or designed landscape which was well maintained, not dense, provided a clear view, was clean and spacious. Again, this shows that not all vegetation blocks views. Well maintained grassy areas, trees or shrubs certainly does not block views; high-canopy trees, spacious, low growing shrubs seem unlikely to provide cover for crime (Kuo and Sullivan, 2001).

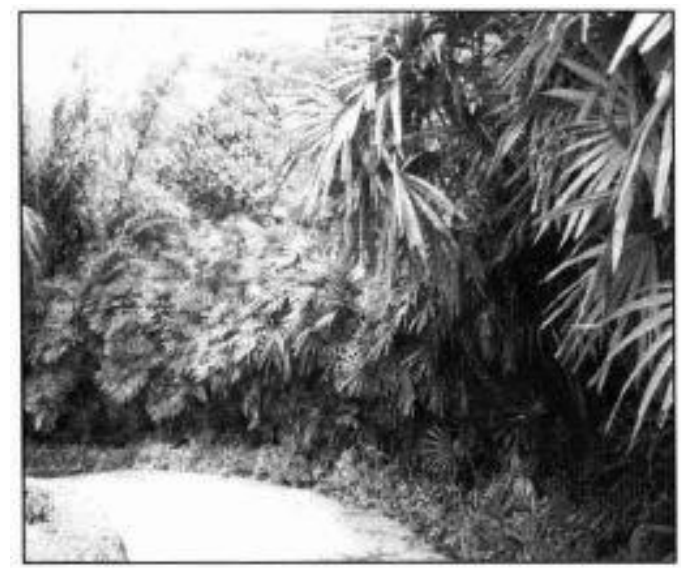

Figure 6: Photo 10 shows unmaintained, tall and bushy vegetation which completely blocks the view of the park user who walks along the pathway.

This shows that species selection for planting purposes in parks should address not only the functional and aesthetic aspects of the city's built-up environment but needs to also consider the safety aspect. This study shows that landscape maintenance is an important factor which influences the social safety of park users. This is a very pertinent issue because a park should be a place for the public to enjoy rather than fear.

A test was also conducted to see whether there were significant differences in the perceptions of personal safety between gender and age. Previous studies have stated that women and elderly people actually feel unsafe in green environments (Burgess, 1988;Jorgensenand Anthopoulou, 2007; Jorgensenetul. 2(02). However, this study did not fully support the idea that a natural landscape was considered 'threatening ' or 'frightening' particularly by women (Burgess, J., Harrison, e M. and Limb, M., 1988). In addition, there was also no significant difference among the respondents from different age groups about personal safety. This might be because about $50 \%$ of the respondents fell between the age group of $21-30$ years. Onlyabout $7 \%$ ofthe respondentswereabove 50 years old. This study only presents preliminary evidence for the idea that a green environment does influence the perception towards social safety. Due to the small sample size, further research is needed to 
confirm the findings.

\subsection{Conclusions}

This study shows that not all vegetation generates fear among people. This study also shows that dense vegetation does link to general fears and to fear of crime in particular. The findings from this study could be considered as a start for a more in-depth study on the relationship between vegetation and personal safety. Further studies on species selection, plant arrangement and maintenance could even enhance the relationship between vegetation and personal safety. Urban design should not only be aesthetically pleasing but also provide a safe environment through proper environmental design such as guidelines on landscaping treatment. This has been stated clearly under the Kuala Lumpur Structure Plan 2020 where the City Hall (DB KL) shall draw up an Urban Design Framework together with a comprehensive set of Urban Design Guidelines to ensure public safety (KLSP 2020, 2(04).

\section{Acknowledgements}

The author is greatly indebted to the Kuala Lumpur City Hall (DBKL) who granted the permission to conduct this study at the Kepong Metropolitan Park.

\section{References}

Bixler, R. and Floyd, M. (1997). "Nature is scary, disgusting and uncomfortable." Environment and Behaviour, 29:443-467.

Brower, S., Docken, K. and Taylor, R.B. (1983). Resident's perceptions of territorial features and perceived local threat. Environment and Behaviour, 15: 4 19-437.

Burgess, J.. Harrison, C.M. and Limb, M. (1988). People, parks and the urban green: A study of popular meanings and values for open spaces in the city. Urban Study. 25:455-473.

Corina,J.M.(1993).What is coefficient alpha? An examination of theory and applications. Jour. Of Applied Psychology, 78(I): 98-104.

Fisher,B.S.andNasar,J.L.(1992).Fear of crime in relation to three exterior site features: Prospect, refuge and escape. Environment and Behaviour, 24:36-65.

Herzog,T.R.and Flynn-Smith,J.A.(200I).Preference and perceived danger as a function of the perceived curvature, length and width of urban alleys . Environment and Behaviour. 33: 653-666.

Jacobs, J. (196 1). The Life and Death of Great American Cities. New York: Vintage Books.

Jorgensen, A. and Anthopoulou, A. (2007). Enjoyment and fear in urban woodlands-docs age make a difference. 
Maruthaveeran, S., / Asian Journal of Environment-Behaviour Studies, ajE-Bs, 1(1), Maiden, December 2016 (p.99-111)

Urban Forestry \& Urban Greening , 6:267-278.

Jorgensen,A., Hitchmough,J.and Calvert,T.(2002).Woodland spaces and edges:their impact on perception of safety and preference. Landscape and Urban Planning. 60: 135-150.

Jorgensen, A., Hitchmough. J. and Dunnett, N. (2007). Woodland as a setting for housing -appreciation and fear and the contribution to residential satisfaction and place identity in Warrington New Town, UK. Landscape and Urhan

Planning, 79:273.

Kaplan, R. (1984). Impact of urban nature: A theoretical analysis. Urban Ecol. 8:189-197.

Kendcl, A.D. and Forbes, SJ. (1997). Urban Nature Conservation: Landscape Management in the Urban Countryside. E \& FN Spon, London.

Kuo, F.E. and Sullivan, W.e. (2001). Environment and Crime in the Inner City: Docs Vegetation Reduce Crime? Environment and Behaviour, 33(3):343-367.

Kuo, F.E., Bacaicoa, M. and Sullivan, W.C. (1998). Transforming Inner-City Landscapes: Trees, Sense of Safety and Preference. Environment and Behaviour, 30:28-59.

Kuala Lumpur Structure Plan 2020. (2004). Dewan Bandaraya Kuala Lumpur (DBKL), Kuala Lumpur.

Ley, D. and Cybriwsky, R. (1974). The spatial ecology of stripped cars. Environmental and Behaviour, 6:53-68.

Maas, J., Sprceuwcnbcrg, P., Van Winsum-Wcstra, M., Vcrhcij, R.A, de Vries, Sand Grocnewcgcn, P.P. (2008). Is green space in the living environment associated with people's feeling of social safety? Environment and Planning (doi: 10.1068/a4196).

Maslow, A. (1954). Motivation and personality. New York: Harper.

McNaghten, P. and Urry, J. (2000). Bodies in the woods. Body \& Society, 6:166-182.

Michael, S. E. and Hull, R.B. (1994). Effects of vegetation on crime in urban parks. Savoy, IL: International Society of Arboriculture Research Trust.

Miethc, T. D. (1995). "Fear and withdrawal from urban life", The Annals of the American Academy of Political and Social Science, Reactions to Crime and Violence. (May, 1995) 539,14-27.

Millward, A. and Mostyn, B. (1989). People and Nature in Cities: The Changing Social Aspects of Planning and Managing Natural Parks in Urban Areas. Urban Wildlife Now: 2. Nature Conservancy Council, Peterborough.

Nasar.T, L. (1982). A model relating visual attributes in the residential environment to fear of crime. Jour. of Environmental Systems, 11:247-255.

Nasar, J.L. and Fisher, B.S. (1993). "Hot spots" of fear and crime: A multi-method investigation. Journal of Environmental Psychology, 13: 187-206.

Ozgtlger, H. and Kendle, A.D. (2006). Public attitudes towards naturalistic versus designed landscape in the city of 
Sheffield (UK). Landscape and Urban Planning 74:139.

Pluncknctt, T.F.T. (1960). Edward I and Criminal Law. Cambridge, UK: Cambridge University Press. Schroeder, H.W. and Anderson, L.M. (1984). Perception of personal safety in urban recreation sites. Jour of Leisure Research 16: 178-194.

Schroeder, H.W. (1989). "Environment, Behaviour and Design Research on Urban Forests." In Advances in Environment, Behaviour and Design, Vo1.2, cds. Ervin H. Zube and Gary T. Moore. New York: Plenum Publishing Corporation.

Shaffer, G.S. and Anderson, L.M. (1985). Perceptions of the security and attractiveness of urban parking lots. Journal of Environmental Psychology. 5:311-323.

Talbot, J.F. and Kaplan, R. (1984). Needs and fears: the response to trees and nature in the inner city. Journal of Arboriculture 25(5):225-233.

Van Winsum-Westra, M. and De Boer, T.A. (2004). Safety in forest and nature? An exploration of subjective and objective aspects of social and physical safety in forest and nature areas, Alterra University of Wageningen, Netherlands. 